\title{
THE
}

\section{Diet Quality and Food Limitation Affect the Dynamics of Body Composition and Digestive Organs in a Migratory Songbird (Zonotrichia albicollis)}

\author{
Barbara J. Pierce \\ Scott R. McWilliams \\ University of Rhode Island, srmcwilliams@uri.edu
}

Follow this and additional works at: https://digitalcommons.uri.edu/nrs_facpubs

Terms of Use

All rights reserved under copyright.

\section{Citation/Publisher Attribution}

Pierce, B. J., \& McWilliams, S. R. (2004). Diet Quality and Food Limitation Affect the Dynamics of Body Composition and Digestive Organs in a Migratory Songbird (Zonotrichia albicollis), Physiological and Biochemical Zoology, 77(3), 471-483. doi: 10.1086/383503 Available at: https://doi.org/10.1086/383503

This Article is brought to you for free and open access by the Natural Resources Science at DigitalCommons@URI. It has been accepted for inclusion in Natural Resources Science Faculty Publications by an authorized administrator of DigitalCommons@URI. For more information, please contact digitalcommons-group@uri.edu. 


\section{Diet Quality and Food Limitation Affect the Dynamics of Body Composition and Digestive Organs in a Migratory Songbird (Zonotrichia albicollis)}

\author{
Barbara J. Pierce* \\ Scott R. McWilliams ${ }^{\dagger}$ \\ Department of Natural Resources Science, University of \\ Rhode Island, 105 Coastal Institute Kingston, Kingston, \\ Rhode Island 02881
}

Accepted 10/23/03 at stopover sites. These alternating periods of fasting and refeeding are associated with dynamic changes in body mass of migrating birds. Early studies suggested that the observed changes in body mass of migrating birds were caused primarily by the deposition and subsequent use of fat (Connell et al. 1960; Odum et al. 1964; Hicks 1967). More recent studies of migrating birds have shown that both body fat and protein are used and restored (Marsh 1984; Piersma 1990; Lindström and Piersma 1993; Karasov and Pinshow 1998; Bordel and Haase 2000). If birds at stopover sites must rebuild used protein reserves before resuming migration, then eating fruits, which often are low in available protein (Herrera 1982; Johnson et al. 1985; Witmer 1998), may slow recovery rates of protein reserves and so increase duration of stopover. Because many species of migratory songbirds eat primarily fruit during fall migration (Martin et al. 1951; Thompson and Willson 1979; Parrish 1997), some studies have examined whether fruits provide adequate nutrients for songbirds (Bairlein 1987; Levey and Karasov 1989; Levey and Grajal 1991; Witmer 1998; Witmer and Van Soest 1998). However, few studies have examined the influence of diet quality on nutrient reserve recovery rates in migratory songbirds (Bairlein 1987; Jordano 1988).

Short-term changes in food intake (e.g., fasting, hyperphagia) during migration directly affect the digestive system of migratory songbirds, which in turn may influence the tempo of migration in these birds (McWilliams and Karasov 2001). Ecological field studies have revealed that recently arrived migrants experience a delay in recovery of body mass followed by a progressive increase in body mass after the first day (Rappole and Warner 1976; Moore and Kerlinger 1987; Lindström 1995; Yong and Moore 1997). Hume and Biebach (1996) showed that migratory garden warblers (Sylvia borin) had reduced small intestine mass after short-duration fasts and that they had significantly lower intake rates on the first day of refeeding than on subsequent days. They suggested that the delay in recovery of body mass in newly arrived migrants was a result of birds having to rebuild gut mass before maximizing food intake and replenishing lost nutrient reserves. If short-term fasting compromises gut function, then birds that periodically eat during migration may not incur as much reduced gut function and so may more quickly rebuild lost nutrient reserves on arrival at a stopover site. Consistent with this hypothesis, Lee et al. (2002) found that yellow-rumped warblers that were food restricted had smaller gut mass and reduced gut function com-
Physiological and Biochemical Zoology 77(3):471-483. 2004. (C) 2004 by The University of Chicago. All rights reserved. 1522-2152/2004/7703-3010\$15.00

${ }^{*}$ Corresponding author; e-mail: bjpierce2@yahoo.com.
${ }^{\dagger}$ E-mail: srmcwilliams@uri.edu.

During migration, birds alternate between periods of shortterm fasting during flight and periods of increased food intake 
Table 1: Composition of two semisynthetic diets fed to white-throated sparrows

\begin{tabular}{|c|c|c|c|}
\hline \multirow[b]{2}{*}{ Ingredients } & \multicolumn{2}{|l|}{ Fruit Diet } & \multirow{2}{*}{$\frac{\text { Grain Diet }}{\% \text { Dry Mass }}$} \\
\hline & $\%$ Wet Mass & $\%$ Dry Mass & \\
\hline Glucose & 16.45 & 65.8 & $\ldots$ \\
\hline Corn $\operatorname{starch}^{\mathrm{a}}$ & $\ldots$ & $\ldots$ & 61.53 \\
\hline Casein $^{\mathrm{b}}$ & 2.5 & 10.0 & 10.0 \\
\hline Amino acid $\operatorname{mix}^{c}$ & .7 & 2.8 & 2.77 \\
\hline Vitamin and minerals mix ${ }^{\mathrm{d}}$ & .25 & 1.0 & 1.0 \\
\hline Salt $\operatorname{mix}^{\mathrm{e}}$ & 1.68 & 6.7 & 5.5 \\
\hline Cellulose $e^{\mathrm{f}}$ & .68 & 2.7 & 5.0 \\
\hline Ground silica sand & $\ldots$ & $\ldots$ & 5.0 \\
\hline Sodium bicarbonate & $\ldots$ & $\ldots$ & 1.0 \\
\hline Choline chloride & $\ldots$ & $\ldots$ & .2 \\
\hline Olive or corn oil ${ }^{g}$ & 1.5 & 6.0 & 8.0 \\
\hline $\operatorname{Agar}^{\mathrm{h}}$ & 1.25 & 5.0 & $\ldots$ \\
\hline Water & 75.0 & $\ldots$ & $\ldots$ \\
\hline \multicolumn{4}{|c|}{$\begin{array}{l}{ }^{\mathrm{b}} \text { Casein (high N): U.S. Biochemical Corp., Cleveland. } \\
{ }^{\mathrm{c}} \text { Amino acid mix: by Murphy and King (1982), all amino acids supplied by Fisher Scientific, }\end{array}$} \\
\hline $\begin{array}{l}\text { Pittsburgh. } \\
{ }^{\mathrm{d}} \text { AIN-76 Vitamin and Mineral } \\
{ }^{\mathrm{e}} \text { Salt mix: Briggs-N salt mixture, } \\
{ }^{\mathrm{f}} \text { Celufil-hydrolyzed: U.S. Biocher } \\
{ }^{\mathrm{g}} \text { Olive oil in the fruit diet, corn }\end{array}$ & $\begin{array}{l}x, I C N \text { Biomedicals } \\
\text { ICN Biomedicals. } \\
\text { ical Corp., Clevelan } \\
\text { il in the grain diet. }\end{array}$ & d. & \\
\hline
\end{tabular}

pared with control birds that were fed ad lib., although on returning to ad lib. feeding, previously restricted birds were immediately able to feed and digest at rates similar to those of control birds. Few studies have compared the effects of fasting and food restriction on gut size and rate of body composition change in a migratory songbird (Karasov and Pinshow 2000; McWilliams and Karasov 2004). No previous study has examined the interactive effects of food limitation and diet quality on gut size and body composition change in a migratory songbird.

In this study, we examined the effects of fasting and food restriction on overall body composition and digestive organs and how these effects interact with diet quality to influence the rate of recovery of nutrient reserves in a migratory songbird. We tested the following hypotheses: (1) fasting and food restriction cause songbirds to simultaneously lose both fat and protein reserves, (2) fasting and food restriction reduce gut size of songbirds, and this, in turn, slows recovery rates of body reserves, and (3) recovery of body reserves after food limitation is slower in birds fed a fruit diet than in birds fed a grain diet because of differences in the nutritional quality of these two diets.

\section{Material and Methods}

\section{Capture and Maintenance of Birds}

White-throated sparrows $(n=55)$ were captured using mist nets between October 25 and December 14, 1998, in Kingston, Rhode Island $\left(41^{\circ} 5^{\prime} \mathrm{N}, 71^{\circ} 5^{\prime} \mathrm{W}\right.$; U.S. Fish and Wildlife Service permit 22923-B, Rhode Island Department of Environmental Management permit 98-87). White-throated sparrows are abundant, short-distance migrants that are primarily granivorous throughout the year. However, during the fall migration period, they may eat mostly fruit (Terres 1996). Thus, they are an excellent species in which to study the effects of food quality and food limitation on the dynamics of nutrient and energy reserves in a migratory songbird.

Birds were immediately banded and weighed $( \pm 0.1 \mathrm{~g})$, and their wing chord was measured $( \pm 0.1 \mathrm{~cm})$. In the laboratory, birds were housed individually in stainless-steel cages (59 $\mathrm{cm} \times 45 \mathrm{~cm} \times 36 \mathrm{~cm})$, at constant temperature $\left(23^{\circ} \mathrm{C}\right)$, and on a light cycle that simulated the natural light cycle at time of capture (11L : 13D light : dark cycle, lights on at 0700 hours). All birds were initially provided ad lib. water and one of two semisynthetic diets (Table $1 ; n=28$ fed fruit diet, $n=27$ fed 
grain diet) and for the first $5 \mathrm{~d}$ were supplemented with $2 \mathrm{~g}$ of cracked corn each day. Nutrient content of the two semisynthetic diets simulated a fruit diet (65\% carbohydrate : $13 \%$ protein : $6 \%$ fat) and a grain diet (62\% carbohydrate : $13 \%$ protein : $8 \%$ fat; Table 1). Use of such semisynthetic diets makes the composition of the diets less ambiguous than diets compounded from raw foodstuffs (Murphy and King 1982). Each day we measured body mass $( \pm 0.1 \mathrm{~g})$ and food intake $( \pm 0.1$ $\mathrm{g}$ wet) of each bird. All procedures related to bird husbandry and care during this experiment conformed to those of Gaunt and Oring (1997) and were approved by University of Rhode Island Institutional Animal Care and Use Committee (A98-09012).

\section{Diets and Feeding Schedules}

All birds were acclimated to the laboratory conditions and to their respective diets for $5 \mathrm{~d}$ before the experiment. After the 5-d acclimation period, birds were randomly assigned to one of three feeding schedules: ad lib. (hereafter called control; $n=10$ fruit fed, 9 grain fed), restricted ( $n=9 /$ diet $)$, and fasted ( $n=9 /$ diet). Control birds continued to receive ad lib. food, and all birds were given ad lib. water. The restricted feeding schedule included feeding periods interrupted with nonfeeding periods to simulate natural conditions of short-distance diurnal migrants, which may intermittently feed throughout the day. The schedule of food restriction was determined by gradually reducing the time that birds were given access to food each day until we observed a decline in body mass at 0700 hours on the following day. Fruit-fed birds were restricted to eating $60 \%$ of their normal daily ad lib. intake (18.81 \pm 0.76 g wet), and grain-fed birds were restricted to eating $50 \%$ of their normal daily ad lib. intake (6.74 $\pm 0.53 \mathrm{~g}$ wet). Restricted birds fed the fruit diet were offered food for five 1-h intervals every other hour during their 11-h light cycle. Restricted birds fed the grain diet were offered food for three 15-min intervals starting at 0800 hours, 1200 hours, and 1600 hours. All food was removed at 1800 hours so that no feeding occurred at night. Fasted birds $(n=9)$ in both diet groups were denied food for 1-2 d.

Restricted and fasted birds remained on their designated feeding schedule until they lost approximately $20 \%$ (mean mass loss: $19.5 \% \pm 2.5 \%$ [range: $17 \%-22 \%$ ]) of their initial prefasted or prerestriction body mass. Once this minimum body mass was achieved, a subset of birds in each diet group was killed, and their digestive organs were measured. The remaining birds ( $n=31$ ) were refed ad lib. for $3 \mathrm{~d}$, and then they were killed, and their digestive organs were measured.

Dry matter food intake $( \pm 0.1 \mathrm{~g})$ was measured daily throughout the experiment. We dried $\left(90^{\circ} \mathrm{C}\right)$ and weighed $( \pm 0.1 \mathrm{~g})$ samples of food offered and remaining to estimate water content and then dry matter intake (DMI) for each sparrow $(\mathrm{DMI}=$ dry mass offered - dry mass of uneaten food $)$.

\section{Organ Collection and Analysis}

Once minimum body mass was achieved after food restriction or fasting, six control birds per diet and three birds from each of the other four treatment groups were killed. The gizzard, liver, and pancreas were removed, rinsed in distilled water, blotted dry, and weighed ( $\pm 0.1 \mathrm{mg}$ ). The small intestine and large intestine were removed, perfused with distilled water, blotted dry, weighed $( \pm 0.1 \mathrm{mg})$, and measured $( \pm 0.1 \mathrm{~cm})$. All organs were then placed back into the carcass, and the whole bird was stored frozen at $-20^{\circ} \mathrm{C}$ for later body composition analysis. After the 3-d refeeding period, this same procedure was repeated on the remaining control birds (four fruit fed, three grain fed) and on the birds from each of the other four treatment groups ( $n=6$ in all four cases).

\section{Total Body Electrical Conductivity Measurements}

We estimated lean and fat mass of live sparrows using an EMSCAN SA-3000 Small Animal Body Composition Analyzer with a Model 3044 detection chamber (Em-Scan, Springfield, Ill.) and a custom-built Plexiglas cylinder to restrain the bird (Karasov and Pinshow 1998). Total body electrical conductivity (TOBEC) measurements of sparrows were taken each day beginning with the day before any food limitation and ending with the third day of recovery. Measurements were made immediately after lights on to ensure birds had empty guts. Measurements were made of the empty cylinder before and immediately after three consecutive measurements of the cylinder with the bird. A bird's TOBEC $E$ value was calculated as the difference between the mean values of the chamber with and without the bird. Using TOBEC to measure body composition allowed us to determine the changes in lean mass within the same individuals over time.

\section{Body Composition Analysis}

It was necessary to obtain the actual body composition of a subset of sparrows to determine the accuracy and precision of TOBEC for estimating lean and fat mass of white-throated sparrows. Bird carcasses were plucked, freeze-dried, weighed $( \pm 0.1 \mathrm{mg})$, and then ground in a small Waring blender. Each ground carcass was placed in a ceramic thimble (30 $\mathrm{mm} \times 80 \mathrm{~mm}$, medium porosity) and refluxed with petroleum ether for $6 \mathrm{~h}$ in a Soxhlet apparatus to measure fat content (Dobush et al. 1985). Total body fat was the extracted fat mass. Lean mass was the body mass at death minus the fat mass and therefore includes all nonfat body components plus feather mass and water mass. 


\section{TOBEC Calibration and Validation}

The TOBEC calibration model was built with 18 sparrows (body mass range $=16.5-26.5 \mathrm{~g}$ ) and validated with six sparrows (body mass range $=17.1-25.1 \mathrm{~g}$ ). Model I least squares linear regression was used to build a predictive model for estimating lean mass given TOBEC $E$ value. An estimate of the precision of the predictive equation is given by the $r^{2}$ value and the standard error of the mean derived from the linear regression. The absolute and relative errors associated with our predictive equation were calculated using six birds that were not used to build the predictive model but for which we had measured lean and fat mass. The absolute error was calculated as the absolute difference between the predicted and measured value (absolute error = |predicted - measured $\mid)$. The relative error was calculated as 100 times the absolute error divided by the measured value $(100 \times(\mid$ predicted - measured $\mid) /$ measured $)$.

Principal component analysis was performed using seven structural measurements (wing length, tail length, tarsus length, head length, bill length, bill width, bill depth; Pyle 1997) from 18 sparrows to determine whether structural size was a significant covariate in the predictive equation. We used multiple linear regression to discern the relationships among lean mass, TOBEC value, and structural measures (Burger 1997).

\section{Statistical Analysis}

Repeated-measures ANOVA (RMANOVA) was used to compare changes in body mass, lean mass, and fat mass during the food-limitation period and to compare body mass, lean mass, fat mass, and daily intake during the refeeding period for each of the diet groups and each of the feeding schedules. One-way ANOVA was used to compare body mass and food intake of sparrows before the experiment. In addition, ANOVA was used to compare body mass, lean mass, and fat mass of sparrows on the final day of food limitation and on the final day of refeeding. ANOVA was also used to compare organ masses of sparrows in each diet and feeding schedule after food limitation and after refeeding. Principal component analysis was used to account for differences in structural size of sparrows, and linear regression was used to create a model to predict lean mass given TOBEC Evalue. We also used linear regression to estimate the proportion of body mass change composed of lean and fat mass. All statistical analyses were performed using the general linear model in SPSS 10.0 (SPSS 1999), and Tukey's HSD (honest significant difference) was used for all post hoc comparisons. Results are reported as means \pm SE.

\section{Results}

Body Mass and Food Intake in Fruit-Fed and Grain-Fed Sparrows before Food Limitation

At capture, there was no significant difference in body mass of birds that were assigned to the two diet groups or the three feeding schedules (FS; ANOVA, diet: $F_{1,49}=0.09, P=0.76$; FS: $F_{2,49}=1.42, P=0.25$; diet $\left.\times \mathrm{FS}: F_{2,49}=2.36, P=0.11\right)$. After acclimation, body masses of grain-fed sparrows $(24.5 \pm 0.4 \mathrm{~g})$ on all three feeding schedules were on average heavier than fruit-fed sparrows $\left(22.8 \pm 0.4 \mathrm{~g}\right.$; ANOVA, diet: $F_{1,49}=10.03$, $P=0.003 ; \quad$ FS: $F_{2,49}=0.089, \quad P=0.92$; $\operatorname{diet} \times$ FS: $F_{2,49}=$ $0.035, P=0.97$ ). During the experimental period (food limitation and refeeding), both fruit-fed and grain-fed control birds maintained constant body mass (RMANOVA, time: $F_{5,25}=$ 1.71, $P=0.17$; diet: $\left.F_{1,5}=6.99, P=0.046\right)$.
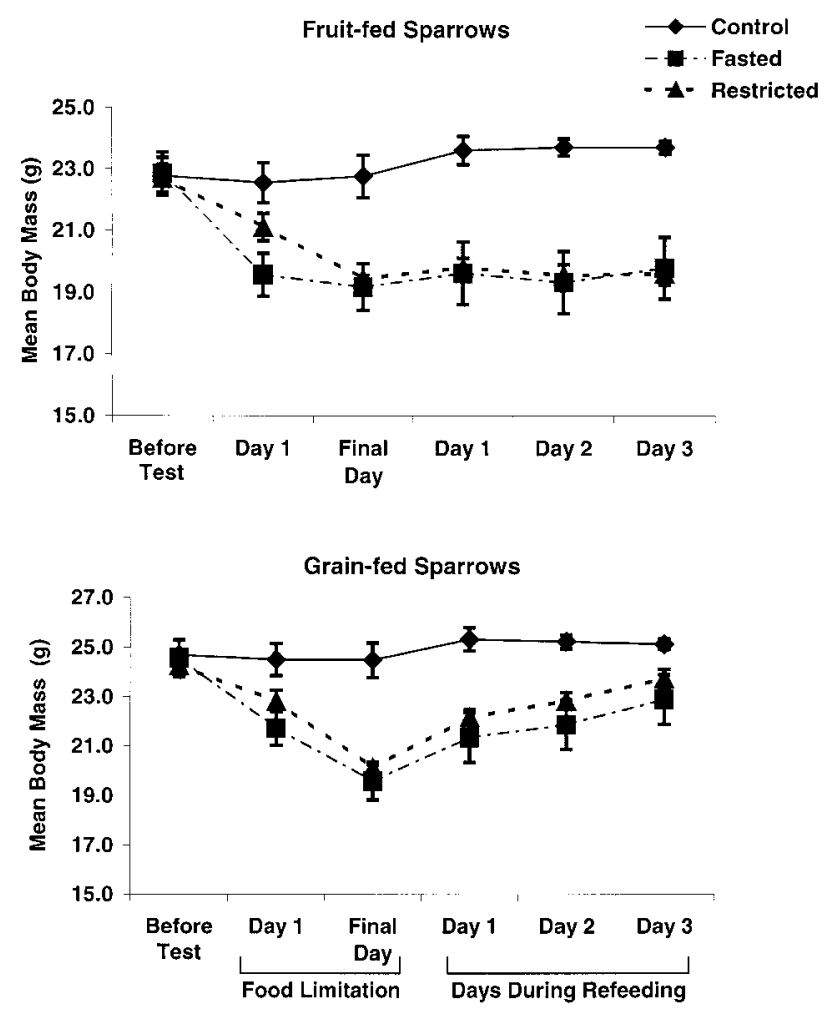

Figure 1. Mean body mass \pm SE of white-throated sparrows fed fruit or grain diets at one of three feeding schedules: control, restricted (50\%-60\% of ad lib.), or fasted (for $1-2 \mathrm{~d}$ ). Restricted ( $n=9 /$ diet) and fasted $(n=9 /$ diet $)$ birds weighed less than control birds $(n=$ 10 fruit fed, $n=9$ grain fed) on the final day of food limitation. On the final day of food limitation, body mass of restricted and fasted birds was similar for birds in both diet groups. During the 3 -d refeeding period, grain-fed birds were heavier than fruit-fed birds, and restricted ( $n=6 /$ diet $)$ and fasted $(n=6 /$ diet $)$ birds weighed less than control birds ( $n=4$ fruit fed, $n=3$ grain fed). Fruit-fed birds that were food limited were unable to increase in body mass, whereas grain-fed birds increased their body mass. 


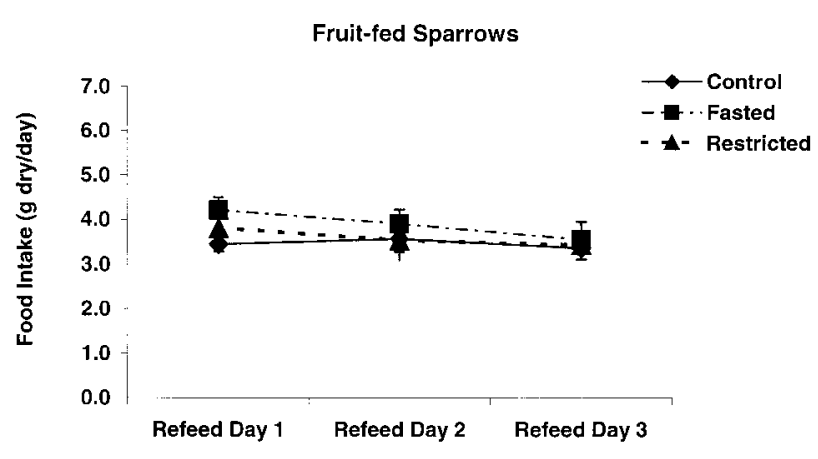

Grain-fed Sparrows

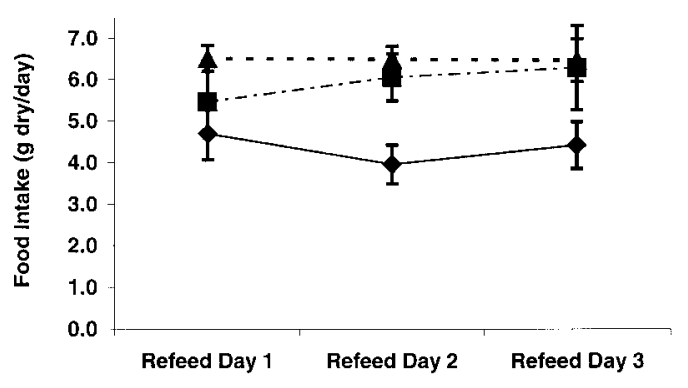

Figure 2. Mean daily dry matter food intake \pm SE of white-throated sparrows fed fruit or grain diets during the 3 -d refeeding period after food limitation. Daily dry matter intake of grain-fed and fruit-fed birds was measured in six birds for the restricted and fasted feeding schedules, in four birds for the control fruit-fed group, and in three birds for the control grain-fed group. During the refeeding period, previously food-limited grain-fed but not fruit-fed birds increased their food intake compared with control birds.

Before food limitation, fruit-fed sparrows ate three times more food each day $(19.3 \pm 0.6 \mathrm{~g}$ wet $)$ than did grain-fed sparrows $(6.2 \pm 0.3 \mathrm{~g}$ wet). However, dry matter intake was significantly higher in grain-fed sparrows $(6.2 \pm 0.2 \mathrm{~g})$ than in fruit-fed sparrows ( $4.9 \pm 0.2 \mathrm{~g})$. Before food limitation, sparrows within the fasted group ate significantly more $(6.1 \pm$ $0.3 \mathrm{~g})$ than did controls $(5.1 \pm 0.3 \mathrm{~g})$ but not more than did sparrows within the restricted group $(5.5 \pm 0.3 \mathrm{~g}$; ANOVA, diet: $F_{1,49}=21.03, P<0.001 ; \mathrm{FS}: F_{2,49}=3.97, P=0.03$; diet $\times \mathrm{FS}:$ $F_{2,49}=1.71, P=0.19$ ).

Effect of Food Limitation and Refeeding on Body Mass and Daily Intake

As expected, food restriction and fasting caused birds to reduce their body mass compared with control birds (ANOVA, FS: $F_{2,49}=30.451, P<0.01$; Fig. 1). After food limitation, body mass of restricted and fasted birds was similar for fruit-fed and grain-fed sparrows (ANOVA, diet: $F_{1,49}=3.621, P=0.06$; diet $\times$ FS: $\left.F_{2,49}=0.655, P=0.52\right)$.

During the 3-d refeeding period, fruit-fed birds that were food limited did not increase in body mass, whereas grain-fed birds that were food limited increased their body mass (RMANOVA, time: $F_{2,50}=15.94, \quad P<0.001$; diet $\times$ time: $F_{2,50}=13.14, P<0.001 ; \quad F S \times$ time: $F_{4,50}=4.58, P=0.003$; diet $\times$ FS $\times$ time: $F_{4,50}=5.039, P=0.002$; Fig. 1). In general, grain-fed birds were significantly heavier than fruit-fed birds, and restricted and fasted birds weighed significantly less than control birds (RMANOVA, diet: $F_{1,25}=13.432, P<0.01$; FS: $F_{2,25}=10.051, P<0.01$; diet $\times$ FS: $F_{2,25}=0.522, P=0.60$; Fig. $1)$.

During the 3-d refeeding period, whole food intake of fruitfed birds $(16.59 \pm 0.54 \mathrm{~g})$ was significantly higher than that of grain-fed birds (5.6 \pm 0.27 g; RMANOVA, diet: $F_{1,25}=$ 195.35, $P<0.01$; time: $\left.F_{2,50}=1.8, P=0.18\right)$. However, dry food intake of grain-fed birds $(5.6 \pm 0.27 \mathrm{~g})$ was significantly higher than that of fruit-fed birds $(3.6 \pm 0.25 \mathrm{~g}$; RMANOVA, diet: $F_{1,25}=27.366, P<0.01$; time: $F_{2,50}=0.15, P=0.86$; Fig. 2). Food intake of restricted $(5.19 \pm 0.29 \mathrm{~g}$ dry) and fasted birds $(4.92 \pm 0.29 \mathrm{~g}$ dry) was generally higher than that of control birds (3.92 $\pm 0.38 \mathrm{~g}$ dry), especially for the grain-fed sparrows (RMANOVA, FS: $F_{2,25}=3.12, P=0.06$; diet $\times$ FS: $\left.F_{2,25}=2.19, P=0.13\right)$.

\section{Effect of Food Limitation and Refeeding on Body Composition}

Predictive Model Given TOBEC. Principal component analysis using seven structural measurements (wing length, tail length, tarsus length, head length, bill length, bill width, bill depth) from 18 sparrows yielded two components (PC1 and $\mathrm{PC} 2)$ that

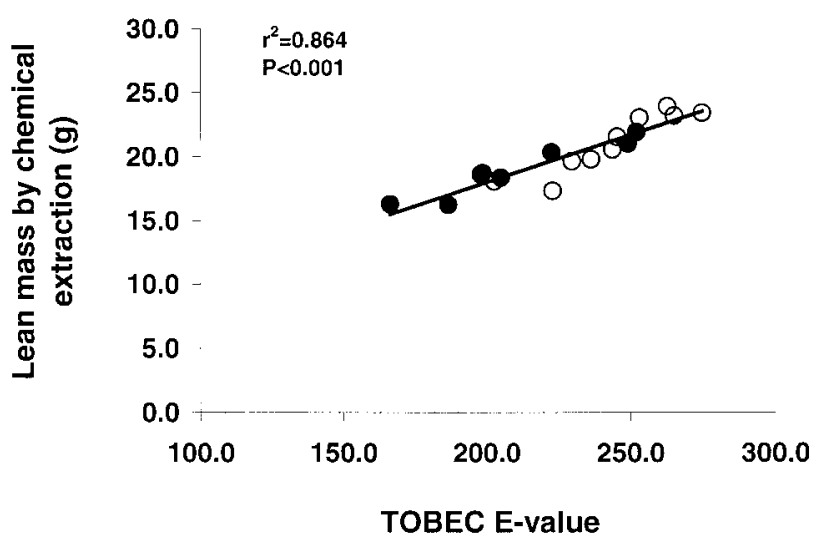

Figure 3. Relationship between lean mass measured by chemical extraction and total body electrical conductivity (TOBEC) $E$ value in white-throated sparrows $(n=18)$. A best-fit least squares linear regression line is shown and its equation [lean mass $=3.123+0.0745$ (TOBEC)] was used to predict lean mass of sparrows given only TOBEC $E$ value. Using this predictive equation, lean mass of sparrows was estimated with precision of $0.62 \mathrm{~g}$ or approximately $3 \%$ error. Open circles are grain-fed sparrows, and closed circles are fruit-fed sparrows. Relationship between lean mass and TOBEC $E$ value was not significantly different between diet groups $(t=1.99, P>0.05)$. 
Table 2: Lean and fat mass (g wet \pm SE) of white-throated sparrows fed fruit or grain diets ad lib. (controls) or immediately after food limitation (either restricted or fasted)

\begin{tabular}{|c|c|c|c|c|c|c|}
\hline \multirow[b]{2}{*}{ Feeding Schedule } & \multicolumn{3}{|c|}{ Fruit Diet } & \multicolumn{3}{|c|}{ Grain Diet } \\
\hline & $n$ & Lean Mass ${ }^{\mathrm{a}}$ & Fat Mass ${ }^{\mathrm{a}}$ & $n$ & Lean Mass ${ }^{\mathrm{a}}$ & Fat Mass ${ }^{\mathrm{a}}$ \\
\hline Control & 10 & $21.21 \pm .75^{\mathrm{A}}$ & $1.62 \pm .32^{\mathrm{A}}$ & 9 & $22.35 \pm .5^{\mathrm{A}}$ & $2.21 \pm .39^{\mathrm{A}}$ \\
\hline Restricted & 9 & $18.46 \pm .29^{\mathrm{B}}$ & $1.03 \pm .3^{\mathrm{A}}$ & 9 & $19.68 \pm .58^{\mathrm{B}}$ & $.65 \pm .2^{\mathrm{B}}$ \\
\hline Fasted & 9 & $18.94 \pm .86^{\mathrm{AB}}$ & $.94 \pm .4^{\mathrm{A}}$ & 9 & $20.05 \pm .32^{\mathrm{B}}$ & $.63 \pm .42^{\mathrm{B}}$ \\
\hline
\end{tabular}

Note. Lean mass was estimated using total body electrical conductivity (TOBEC). Fat mass was calculated by subtracting estimated lean mass from measured body mass. Lean mass was significantly greater in grain-fed than in fruit-fed sparrows, food-limited sparrows had significantly less lean mass than did controls, and grain-fed sparrows that were food limited had significantly less fat mass than did controls (although fat mass of grain-fed sparrows was not significantly different from fruit-fed sparrows).

${ }^{a}$ Means with the same letters within columns are not significantly different $(P>0.05)$ on the basis of ANOVA within each diet.

explained $48 \%$ and $23 \%$ of the variance in structural size, respectively. Only PC1 was found to be significantly correlated with lean mass $\left(F_{1,16}=4.175, P=0.045\right)$, although the relationship was relatively weak $\left(r^{2}=0.228, \mathrm{SE}=2.18\right)$. In addition, backward stepwise linear regression resulted in a predictive model that included only TOBEC $E$ value $\left(r^{2}=0.84\right.$, $\mathrm{SE}=0.99$ ) and the removal of PC1 (model with PC1 and $E$ value; $r^{2}=0.84, \mathrm{SE}=1.02$ ). Thus, we built a linear regression model for predicting lean mass given only TOBEC $E$ value.

TOBEC $E$ value was positively related to lean mass $\left(F_{1,16}=101.38, P<0.001 ; r^{2}=0.864, \mathrm{SE}=0.9210\right.$; Fig. 3$)$. The relationship between TOBEC $E$ value and lean mass was not significantly different between diet groups $(t=1.99, P>0.05$; Fig. 3). The following linear regression equation, lean mass $=3.123+0.0745$ (TOBEC), was used to estimate lean mass of white-throated sparrows given only TOBEC $E$ value. Using this predictive equation, we estimated the lean mass of six sparrows that were not used to build the model with a precision of $0.62 \mathrm{~g}$ or $3.06 \%$ relative error. We used this predictive equation to directly estimate lean mass and indirectly estimate fat mass of sparrows throughout the experiment.
Changes in Body Composition of Sparrows. On the final day of food limitation, fruit-fed birds had significantly less lean mass than did grain-fed birds, and food-limited birds (both restricted and fasted) had significantly less lean mass than did control birds (ANOVA, diet: $F_{1,55}=5.686, P=0.02$; FS: $F_{2,55}=12.2$, $P<0.001$; diet $\times$ FS: $F_{2,55}=0.01, P=0.99$; Table 2). Fat mass of fruit-fed sparrows was not significantly different from that of grain-fed sparrows, and food-limited birds (both restricted and fasted) had significantly less fat mass than did control birds (ANOVA, diet: $F_{1,55}=0.01, P=0.91$; FS: $F_{2,55}=6.93, P=$ 0.002 ; diet $\times$ FS: $F_{2,55}=1.27, P=0.29$; Table 2). Separate analyses of fruit-fed versus grain-fed birds confirmed that feeding schedule had a significant effect on body composition. Restricted birds fed the fruit diet had significantly less lean mass than did the control birds (ANOVA, FS: $F_{2,28}=4.75, P=$ 0.02; Table 2). Restricted and fasted birds fed the grain diet had significantly less lean and fat mass than did control birds (ANOVA, FS: $F_{2,27}=9.15, P=0.001 ;$ FS: $F_{2,27}=6.68, P=$ 0.005 ; Table 2).

We estimated the proportional change in fat and lean mass during food limitation by calculating the difference in fat and

Table 3: Lean and fat mass ( $\mathrm{g}$ wet $\pm \mathrm{SE}$ ) of white-throated sparrows fed fruit or grain diets ad lib. (control) or immediately after the 3-d refeeding period after food limitation (either restricted or fasted)

\begin{tabular}{|c|c|c|c|c|c|c|}
\hline \multirow[b]{2}{*}{ Feeding Schedule } & \multicolumn{3}{|c|}{ Fruit Diet } & \multicolumn{3}{|c|}{ Grain Diet } \\
\hline & $n$ & Lean Mass ${ }^{\mathrm{a}}$ & Fat Mass ${ }^{\mathrm{a}}$ & $n$ & Lean Mass ${ }^{\mathrm{a}}$ & Fat Mass ${ }^{\mathrm{a}}$ \\
\hline Control & 4 & $21.82 \pm .36^{\mathrm{A}}$ & $1.90 \pm .43^{\mathrm{A}}$ & 3 & $22.18 \pm .36^{\mathrm{A}}$ & $2.95 \pm .34^{\mathrm{A}}$ \\
\hline Restricted & 6 & $19.47 \pm .39^{\mathrm{AB}}$ & $.32 \pm .21^{\mathrm{B}}$ & 6 & $22.28 \pm .81^{\mathrm{A}}$ & $1.52 \pm .51^{\mathrm{A}}$ \\
\hline Fasted & 6 & $19.05 \pm .9^{\mathrm{B}}$ & $.82 \pm .27^{\mathrm{AB}}$ & 6 & $20.74 \pm .26^{\mathrm{A}}$ & $2.31 \pm .82^{\mathrm{A}}$ \\
\hline
\end{tabular}

Note. Lean mass was estimated using total body electrical conductivity (TOBEC). Fat mass was calculated by subtracting estimated lean mass from measured body mass. Lean and fat mass were significantly greater in grain-fed than in fruitfed sparrows, and feeding schedule had a significant effect on lean and fat mass of fruit-fed sparrows. Grain-fed sparrows that were food limited had body composition similar to that of control sparrows by the final day of the 3-d refeeding period, whereas fruit-fed sparrows had less lean and fat mass compared with controls.

${ }^{a}$ Means with the same letters within columns are not significantly different $(P>0.05)$ on the basis of ANOVA within each diet. 

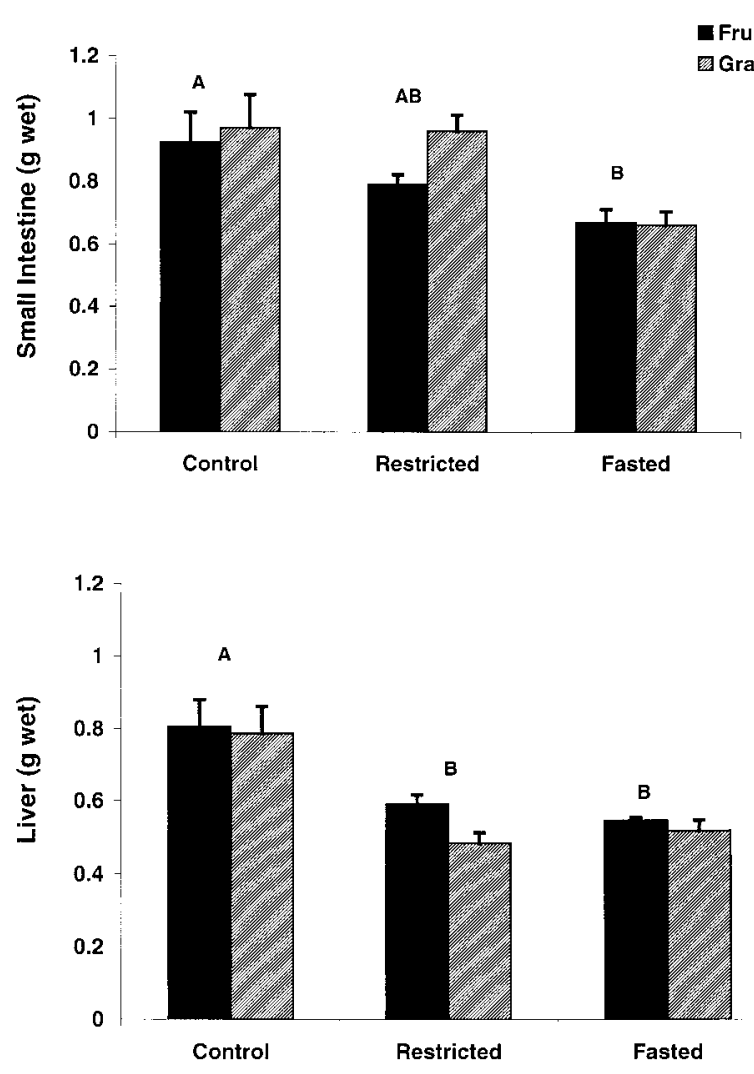

Figure 4. Small intestine and liver mass (g wet \pm SE) of white-throated sparrows fed fruit or grain diets either ad lib. (control), at 50\%-60\% of ad lib. (restricted), or fasted (for 1-2 d). On the final day of food limitation, fasted ( $n=3 /$ diet) birds had lighter small intestines than did control birds $(n=6 /$ diet $)$, and restricted $(n=3 /$ diet $)$ and fasted birds had lighter livers than did control birds. Differences in letters above each pair of bars denote significant differences at $P<0.05$ between feeding schedules.

lean mass of individual birds before and after food limitation. If all body mass change caused by food limitation was fat mass, then (1) the relationship between change in body mass and change in fat mass would be isometric (i.e., slope of 1.0) and (2) there would be no relationship between change in body mass and change in lean mass (i.e., slope of 0.0). In fact, the slope of the relationship between the change in body mass $\left(\Delta M_{\mathrm{b}}\right)$ and change in fat mass $(\Delta F)$ during food limitation was $0.81\left(R^{2}=0.497,(\Delta F)=0.807\left(\Delta M_{\mathrm{b}}\right)-1.493\right)$, and that between $\left(\Delta M_{\mathrm{b}}\right)$ and change in lean mass $(\Delta L)$ was $0.19\left(R^{2}=\right.$ $0.0535,(\Delta L)=0.192\left(\Delta M_{\mathrm{b}}\right)-1.493 \mathrm{P}$. Thus, food-limited sparrows simultaneously used both protein and fat reserves during food limitation.

On the final day of refeeding, grain-fed sparrows had significantly greater lean and fat mass than did fruit-fed sparrows (ANOVA for lean mass, diet: $F_{1,31}=8.89, P=0.006$; FS: $F_{2,31}=4.64, \quad P=0.02$; $\operatorname{diet} \times \mathrm{FS}: F_{2,31}=1.57, \quad P=0.23$; ANOVA for fat mass, diet: $F_{1,31}=8.26, \quad P=0.008$; FS:
$\left.F_{2,31}=3.67, \quad P=0.04 ; \quad \operatorname{diet} \times \mathrm{FS}: F_{2,31}=0.89, \quad P=0.92\right)$. Fasted birds fed the fruit diet had significantly less lean mass than did the control birds (ANOVA, FS: $F_{2,16}=4.33, P=$ 0.04; Table 3). Restricted birds fed the fruit diet had significantly less fat mass than did control birds (ANOVA, FS: $F_{2,16}=7.02$, $P=0.009$; Table 3). Restricted and fasted birds fed the grain diet had similar lean and fat mass compared with control birds by the final day of the 3 -d refeeding period (ANOVA, FS: $F_{2,15}=0.94, P=0.42$; FS: $F_{2,15}=2.17, P=0.16$; Table 3).

We estimated the proportional change in fat and lean mass during recovery as described previously for the food limitation period, but we did so only for grain-fed sparrows because fruitfed sparrows did not regain body mass during the recovery period. The slope of the relationship between the change in body mass $\left(\Delta M_{\mathrm{b}}\right)$ and change in fat mass $(\Delta F)$ during recovery was $0.40\left(R^{2}=0.154,(\Delta F)=0.399\left(\Delta M_{\mathrm{b}}\right)-0.514\right)$, and that between $\left(\Delta M_{\mathrm{b}}\right)$ and change in lean mass $(\Delta L)$ was 0.60 $\left(R^{2}=0.292,(\Delta L)=0.601\left(\Delta M_{\mathrm{b}}\right)-0.4514\right)$. Thus, grain-fed sparrows simultaneously regained both protein and fat reserves during recovery from food limitation.

\section{Effect of Food Limitation and Refeeding on Gut Morphology}

After food limitation, restricted and fasted birds had significantly lighter livers than did control birds (diet: $F_{1,18}=0.743$, $P=0.40 ; \quad$ FS: $F_{2,18}=10.78, \quad P=0.001 ; \operatorname{diet} \times$ FS: $F_{2,18}=$ $0.212, P=0.81$; Fig. 4 ), and fasted but not restricted birds had significantly lighter small intestines than did control birds (diet: $F_{1,18}=0.731, P=0.404 ; \mathrm{FS}: F_{2,18}=4.425, P=0.027$; diet $\times$ FS: $F_{2,18}=0.354, P=0.70$; Fig. 4). In addition, fruitfed birds had significantly longer large intestines than did grainfed birds (Table 4). No other significant differences in gut morphology were found for birds killed immediately after food limitation (Table 4).

After the 3-d refeeding period, grain-fed birds had significantly heavier small intestines compared with fruit-fed birds, although there was a significant interaction between diet and feeding schedule (ANOVA, diet: $F_{1,25}=7.823, P=0.01$; FS: $F_{2,25}=1.114, P=0.34$; diet $\times$ FS: $F_{2,25}=4.587, P=0.02$; Fig. $5)$. Restricted grain-fed birds had the heaviest small intestines, whereas restricted fruit-fed birds had the lightest small intestines (Fig. 5). Restricted birds had significantly heavier livers than did control or fasted birds, with restricted grain-fed birds having the heaviest livers and control grain-fed birds having the lightest livers (ANOVA, diet: $F_{1,25}=1.309, P=0.26$; FS: $F_{2,25}=8.513, P=0.002$; $\operatorname{diet} \times \mathrm{FS}: F_{2,25}=4.228, P=0.03$; Fig. 5). No other significant differences in gut morphology were found for birds killed after the 3-d refeeding period (Table 5). 
Table 4: Mass ( $\mathrm{mg}$ wet $\pm \mathrm{SE}$ ) and length $(\mathrm{mm} \pm \mathrm{SE})$ of digestive organs of white-throated sparrows that were fed fruit or grain diets according to one of three feeding schedules: control (ad lib.), fasted, or restricted

\begin{tabular}{|c|c|c|c|c|c|c|}
\hline $\begin{array}{l}\text { Diet and Feeding } \\
\text { Schedule }\end{array}$ & $n$ & $\begin{array}{l}\text { Large Intestine } \\
(\mathrm{mg})\end{array}$ & $\begin{array}{l}\text { Pancreas } \\
(\mathrm{mg})\end{array}$ & $\begin{array}{l}\text { Gizzard } \\
(\mathrm{mg})\end{array}$ & $\begin{array}{l}\text { Small Intestine } \\
(\mathrm{mm})\end{array}$ & $\begin{array}{l}\text { Large Intestine } \\
(\mathrm{mm})\end{array}$ \\
\hline \multicolumn{7}{|l|}{ Fruit: } \\
\hline Control & 6 & $40.0 \pm 11.0$ & $100.0 \pm 9.0$ & $715.1 \pm 62.0$ & $157.33 \pm 6.11$ & $10.00 \pm 1.09$ \\
\hline Restricted & 3 & $39.5 \pm 10.0$ & $75.2 \pm 8.0$ & $655.0 \pm 52.0$ & $154.0 \pm 11.02$ & $12.33 \pm 1.76$ \\
\hline Fasted & 3 & $43.4 \pm 13.0$ & $72.0 \pm 17.0$ & $772.5 \pm 85.0$ & $153.67 \pm 8.17$ & $11.67 \pm 2.40$ \\
\hline \multicolumn{7}{|l|}{ Grain: } \\
\hline Control & 6 & $40.0 \pm 6.0$ & $90.0 \pm 7.0$ & $673.2 \pm 59.0$ & $156.67 \pm$ & $7.83 \pm .60$ \\
\hline Restricted & 3 & $31.7 \pm 4.0$ & $102 \pm 10.0$ & $546.7 \pm 39.0$ & $160.67 \pm$ & $10.00 \pm 1.00$ \\
\hline Fasted & 3 & $27.6 \pm 3.0$ & $78.8 \pm 8.0$ & $609.6 \pm 38.0$ & $145.67 \pm$ & $8.00 \pm .00$ \\
\hline \multicolumn{7}{|l|}{ Statistical analysis: } \\
\hline \multicolumn{7}{|l|}{ Diet: } \\
\hline$F_{1,18}$ & & 1.743 & .71 & 3.552 & .013 & 7.396 \\
\hline$P$ & & .20 & .41 & .07 & .91 & .014 \\
\hline \multicolumn{7}{|c|}{ Feeding schedule: } \\
\hline$F_{2,18}$ & & .267 & 2.30 & 1.158 & .667 & 1.482 \\
\hline$P$ & & .77 & .13 & .34 & .53 & .25 \\
\hline \multicolumn{7}{|l|}{ Diet $\times$ FS: } \\
\hline$F_{2,18}$ & & .080 & 2.44 & .465 & .431 & .146 \\
\hline$P$ & & .92 & .12 & .64 & .66 & .87 \\
\hline
\end{tabular}

Note. Control birds were killed on the same day as food-limited birds, which was immediately after restricted and fasted birds had finished their food limitation. Bold type denotes significant difference $(P<0.05)$ in large intestine length between birds fed each diet.

\section{Discussion}

Food Limitation and Refeeding Caused Changes in both Protein and Fat Reserves

Food limitation caused white-throated sparrows to reduce both lean and fat reserves with on average $20 \%$ of the decline in body mass composed of lean mass. When grain-fed sparrows increased their body mass after food limitation, on average $60 \%$ of the increase in body mass was composed of lean mass. Other studies have documented simultaneous changes of protein and fat in birds. For example, Karasov and Pinshow (1998) found that in blackcaps (Sylvia atricapilla) for every gram of body mass lost during fasting or gained during refeeding, about $40 \%$ was lean mass. LeMaho et al. (1981) found that for every kilogram of body mass lost in fasting geese, $37 \%$ was lean mass. For garden warblers (Biebach 1990; Klaassen and Biebach 1994), thrush nightingales (Luscinia luscinia; Klaassen et al. 1997), willow warblers (Phylloscopus trochilus; Biebach 1990), and several species of waders (Charadrii; Piersma 1990; Zwarts et al. 1990), $20 \%-50 \%$ of the change in total body mass was lean mass. Given that birds cannot eat during migratory flights, these results suggest that during migration stopovers, birds must rebuild both lean and fat reserves. These estimates of proportional use of lean tissue may underestimate protein catabolism for a flying bird, however, because of the much higher metabolism associated with flight. Regardless of the quantitative amount of lean mass lost and gained during migration, what seems clear is that migratory birds at stopover sites likely require dietary sources of both protein and energy to rebuild used body reserves.

Changes in lean mass of birds may involve catabolism or anabolism of several protein-containing tissues including pectoral muscle (Lindström et al. 2000), leg muscle (McLandress and Raveling 1981), heart (Piersma et al. 1999), and digestive organs such as intestine, liver, kidney, and stomach (Piersma et al. 1999; McWilliams and Karasov 2001, 2004). For migrating red knots (Calidris canutus), sizes of pectoral muscle and heart were correlated with body mass, whereas those of leg muscles and digestive organs were correlated with rate of body mass change (Piersma et al. 1999). For migrating blackcaps, 44\% of the decline in lean mass caused by fasting was represented by a decline in mass of stomach, small intestine, and liver (Karasov and Pinshow 1998). For white-throated sparrows, we found that $22 \%$ of the decline in lean mass caused by fasting or food restriction was represented by a decline in mass of the same three organs. Thus, although digestive organs constitute only about $10 \%$ of a bird's lean mass (Daan et al. 1990; Karasov and Pinshow 1998), dynamic short-term changes in these organs are a major component of lean mass change in migratory birds. 

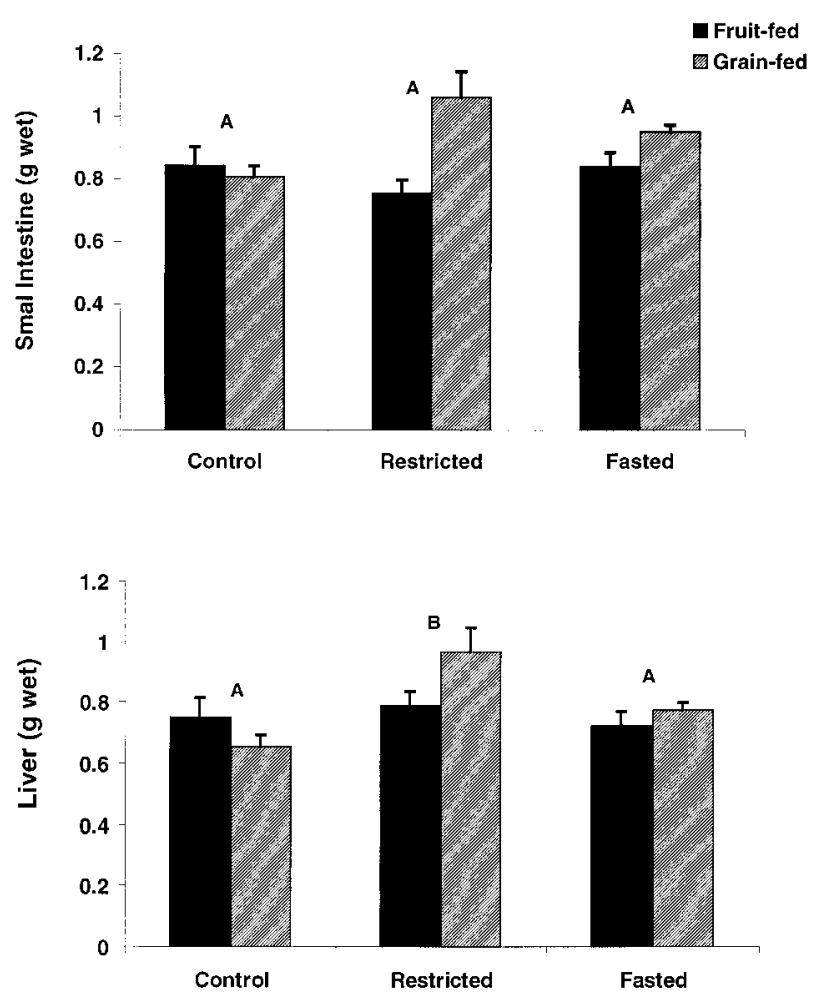

Figure 5. Small intestine and liver mass (g wet \pm SE) of white-throated sparrows after the 3 -d refeeding period. Grain-fed birds had heavier small intestines than did fruit fed birds. Restricted grain-fed sparrows had the heaviest small intestines, whereas restricted fruit-fed sparrows had the lightest small intestines. Restricted $(n=6 /$ diet $)$ birds had heavier livers than did control ( $n=4$ fruit fed, $n=3$ grain fed) or fasted ( $n=6 /$ diet) birds. Differences in letters above each pair of bars denote significant differences at $P<0.05$ between feeding schedules.

\section{Phenotypic Flexibility in Gut Size and Its Ecological Implications}

White-throated sparrows that were fasted or food restricted had lighter livers than did control birds, and fasted sparrows had lighter small intestines than did food-restricted or control birds. Similar reductions in digestive organs associated with food limitation have been observed in shorebirds (Piersma 1998; Piersma and Gill 1998), warblers (Biebach 1998; Karasov and Pinshow 1998; Lee et al. 2002), gulls (Alonso-Alvarez and Ferrer 2001), and many other birds (reviewed by Stark 1999; McWilliams and Karasov 2001, 2004).

What are the ecological implications of having smaller guts for migrating birds? We have shown that digestive organs of white-throated sparrows were reduced by fasting and that when fasted grain-fed sparrows were subsequently provided ad lib. food, their food intake was reduced, relative to restricted birds, for $1 \mathrm{~d}$. In contrast, when sparrows were food restricted, digestive organs were also reduced, but food intake of grain-fed sparrows was at least $40 \%$ higher than that of controls on all
$3 \mathrm{~d}$ after the food restriction while both groups were fed ad lib. Other recent studies confirm that fasting and food restriction reduce digestive organs in migratory songbirds and that these reductions may limit food intake primarily in fasted birds (Klaassen and Biebach 1994; Hume and Biebach 1996; Klaassen et al. 1997; Karasov and Pinshow 2000; Lee et al. 2002). This would suggest that such a digestive constraint is most likely to limit refueling rates in long-distance migrants or in other migrants that do not feed for at least a day at a time (McWilliams and Karasov 2004). In fact, an initial delay in recovery of body reserves has been observed in free-living long-distance migratory songbirds at stopover sites (e.g., Biebach 1998; Gannes 2002).

After the 3-d refeeding period, food-limited grain-fed birds had heavier small intestine and liver mass than did control birds. For these grain-fed birds, the timescale of depletion and recovery of digestive organs such as small intestine and liver was $<3 \mathrm{~d}$. This is consistent with other bird studies that showed increases in digestive organs within 1-6 d after changes in food quantity (Stark 1999; McWilliams and Karasov 2001, 2004). For an actively migrating bird, however, the digestive response to refeeding may be slow enough to limit food intake and thus the rate of refueling. For example, Gannes (2002) and Karasov and Pinshow (2000) found that body mass gain of blackcaps at a stopover site in Israel was delayed for 1-2 d, and they suggested that reductions in digestive organs limited food intake and hence delayed mass gain.

\section{The Inadequacy of Fruit for Recovery of Body Reserves in Migratory Birds}

Given that migratory birds must use and rebuild protein as well as fat reserves, diets that provide primarily carbohydrates and fats (e.g., fruit) may not provide sufficient protein (Witmer 1998; Levey and Martínez del Rio 2001). In addition, diets that contain primarily nonnutritive components (e.g., fruits with mostly water, indigestible fiber, or plant secondary compounds) may be too dilute to satisfy a bird's energy and nutrient requirements (Levey and Grajal 1991). For example, many species of Palearctic songbirds fed only fruit were unable to maintain their body mass (Berthold 1976; Bairlein 1990; Bairlein and Gwinner 1994). In general, migratory songbirds fed a mixed diet of fruit and insects gained body mass faster than when fed either fruit or insects (Bairlein and Gwinner 1994; Parrish 2000).

In our study, food-limited sparrows that were fed the grain diet during recovery were able to increase food intake and digestive organs and regain body mass on return to ad lib. feeding. In contrast, food-limited sparrows that were fed the fruit diet during recovery did not increase food intake or digestive organs and did not regain lost body reserves during the 3 -d recovery period. Thus, diet clearly influenced the ability of sparrows to recover from food limitation. 
Table 5: Mass ( $\mathrm{mg}$ wet $\pm \mathrm{SE})$ and length $(\mathrm{mm} \pm \mathrm{SE})$ of digestive organs of white-throated sparrows that were fed fruit or grain diets according to one of three feeding schedules: control (ad lib.), fasted, or restricted

\begin{tabular}{|c|c|c|c|c|c|c|}
\hline $\begin{array}{l}\text { Diet and Feeding } \\
\text { Schedule }\end{array}$ & $n$ & $\begin{array}{l}\text { Large Intestine } \\
(\mathrm{mg})\end{array}$ & $\begin{array}{l}\text { Pancreas } \\
(\mathrm{mg})\end{array}$ & $\begin{array}{l}\text { Gizzard } \\
(\mathrm{mg})\end{array}$ & $\begin{array}{l}\text { Small Intestine } \\
(\mathrm{mm})\end{array}$ & $\begin{array}{l}\text { Large Intestine } \\
(\mathrm{mm})\end{array}$ \\
\hline \multicolumn{7}{|l|}{ Fruit: } \\
\hline Control & 4 & $40.0 \pm 4.0$ & $100.0 \pm 11.0$ & $552.5 \pm 37.0$ & $148.75 \pm 4.70$ & $9.50 \pm 1.55$ \\
\hline Restricted & 6 & $33.5 \pm 4.0$ & $88.6 \pm 10.0$ & $583.0 \pm 16.0$ & $148.33 \pm 2.76$ & $9.83 \pm .65$ \\
\hline Fasted & 6 & $31.0 \pm 2.0$ & $92.5 \pm 12.0$ & $623.0 \pm 39.0$ & $164.67 \pm 7.46$ & $9.33 \pm .92$ \\
\hline \multicolumn{7}{|l|}{ Grain: } \\
\hline Control & 3 & $30.0 \pm 4.0$ & $90.0 \pm$ & $514.4 \pm 37.0$ & $155.33 \pm 2.67$ & $10.00 \pm 1.0$ \\
\hline Restricted & 6 & $42.0 \pm 4.0$ & $86.4 \pm 7.0$ & $648.8 \pm 52.0$ & $157.17 \pm 4.34$ & $9.33 \pm .76$ \\
\hline Fasted & 6 & $35.0 \pm 5.0$ & $99.4 \pm 5.0$ & $654.0 \pm 42.0$ & $157.17 \pm 2.07$ & $8.17 \pm .95$ \\
\hline \multicolumn{7}{|l|}{ Statistical analysis: } \\
\hline \multicolumn{7}{|l|}{ Diet: } \\
\hline$F_{1,25}$ & & .263 & .249 & .327 & .433 & .232 \\
\hline$P$ & & .61 & .62 & .57 & .52 & .63 \\
\hline \multicolumn{7}{|c|}{ Feeding schedule: } \\
\hline$F_{2,25}$ & & .838 & .576 & 2.946 & 2.254 & .637 \\
\hline$P$ & & .44 & .57 & .07 & .13 & .54 \\
\hline \multicolumn{7}{|l|}{ Diet $\times$ FS: } \\
\hline$F_{2,25}$ & & 1.599 & .697 & .695 & 1.928 & .324 \\
\hline$P$ & & .22 & .51 & .51 & .17 & .73 \\
\hline
\end{tabular}

Note. Control birds were killed on the same day as food-limited birds, which was immediately after restricted and fasted birds had finished their 3-d refeeding period.

The inability of fruit-fed birds to regain body mass after food limitation suggests a diet-related digestive constraint. Recall that the two diets contained similar amounts of protein $(13 \%$ in the fruit and grain diet), fat ( $6 \%$ and $8 \%$, respectively), and carbohydrate $(66 \%$ and $62 \%$, respectively) on a dry matter basis. However, the two diets were quite different in nutrient composition as fed to the birds because the fruit diet contained $75 \%$ water, whereas the grain diet contained essentially no water. After food limitation, sparrows fed the fruit diet ate 2.5 times more wet food per day but obtained 35\% less energy and nutrients per day compared with sparrows fed the grain diet because of the different water contents of the two diets. This level of food intake was inadequate for fruit-fed sparrows as indicated by their inability to recover the nutrient reserves lost during food limitation. Witmer (1998) also found that daily food intake and rates of energy assimilation in songbirds were constrained by digestive processing of dilute fruit diets.

We suggest that fruit-fed sparrows were limited in their food intake by a digestive constraint associated with the water content of the fruit diet. Although birds that primarily eat nectar can cope with excessive water intake, this ability is not the norm among terrestrial vertebrates (Martínez del Rio et al. 2001). Most ingested water is absorbed from the intestine (McWhorter and Martínez del Rio 2000) and so must be processed by the kidneys and eliminated into the large intestine (Goldstein and Skadhauge 2000). Extraordinary water con- sumption leads to dilution of blood plasma that can decrease concentrations of necessary solutes (e.g., sodium) in the plasma to toxic levels (Faenestil 1977; Gevaert et al. 1991).

Our study was not designed to elucidate the physiological mechanism(s) that constrains intake in sparrows fed dilute diets such as fruit. However, our results are consistent with the predictions of a model presented by McWhorter and Martínez del Rio (2000) that suggests a digestive constraint limits intake in nectar-feeding birds especially in energy-demanding situations (e.g., while increasing body reserves, when exposed to cold temperatures). The predictions of their model that were consistent with our results were that (1) before food limitation, fruit-fed birds ate three times more food (g wet) than did grainfed birds, while both groups of birds maintained their body mass. This result provides a good example of compensatory feeding whereby birds increase their food intake to compensate for decreased energy and nutrient density of their diet. In addition, (2) after food limitation, when sparrows with a compromised digestive system were attempting to rebuild lost body reserves, birds fed the higher energy and nutrient density diet (i.e., grain) were able to increase their food intake, whereas birds fed the more dilute diet (i.e., fruit) were unable to increase their food intake and so did not regain lost body reserves. This result suggests that digestive constraints are most likely to impact migrating birds when energy expenditure is highest and diets are most dilute (i.e., birds that eat fruit to fuel migration). 
Interactive Effects of Food Limitation and Diet Quality on Body Composition and Digestive Organs of Migratory Birds

Diet quality and type of food limitation affected the recovery of body reserves in white-throated sparrows. Fasted and foodrestricted sparrows were unable to regain body reserves when fed the fruit diet. For sparrows fed the grain diet, those birds that were initially fasted showed a 1-d delay in recovery of body reserves, whereas birds that were initially food restricted immediately increased food intake and body reserves on return to ad lib. feeding. Thus, there was a strong interaction between the effects of food limitation and diet quality on the dynamics of body composition and digestive organs in white-throated sparrows. Similarly, white-crowned sparrows (Zonotrichia leucophrys) and blackcaps that were food restricted were able to immediately increase nutrient assimilation rate and food intake, whereas fasted birds could not (Murphy et al. 1989; Karasov and Pinshow 2000).

The interactive effects of food limitation and diet quality have important implications for both long-distance and shortdistance migrants. Long-distance migrants that fast for at least $1 \mathrm{~d}$ may have limited food intake because of the negative affects of fasting on digestive organs. Short-distance migrants that continue to feed intermittently each day during migration may encounter no such digestive constraint. However, our results suggest that the quality of the diet at stopover sites can directly affect the rate of recovery of body reserves in migratory birds and hence the pace of their migration.

\section{Acknowledgments}

We thank Jason Osenkowski for his help with capturing birds in the field. Michael Capirchio, Kim Frazer, Heather Hamilton, Chris Hitchner, and Jennifer Podhajski provided excellent care for the captive birds. This is contribution 3994 for the University of Rhode Island Agricultural Experiment Station. This work was supported by USDA grant 538748 and the National Science Foundation (IBN-9984920).

\section{Literature Cited}

Alonso-Alvarez C. and M. Ferrer. 2001. A biochemical study of fasting, subfeeding, and recovery processes in yellowlegged gulls. Physiol Biochem Zool 74:703-713.

Bairlein F. 1987. Nutritional requirements for maintenance of body weight and fat deposition in the long-distance migratory garden warbler, Sylvia borin. Comp Biochem Physiol 86A:337-347.

- 1990. Nutrition and food selection in migratory birds. Pp. 198-213 in E. Gwinner, ed. Bird Migration: Physiology and Ecophysiology. Springer, Berlin.

Bairlein F. and E. Gwinner. 1994. Nutritional mechanisms and temporal control of migratory energy accumulation in birds. Annu Rev Nutr 14:187-215.

Berthold P. 1976. The control and significance of animal and vegetable nutrition in omnivorous songbirds. Ardea 64:140 154.

Biebach H. 1990. Strategies of trans-sahara migrants. Pp. 352367 in E. Gwinner, ed. Bird Migration: Physiology and Ecophysiology. Springer, Berlin.

- 1998. Phenotypic organ flexibility in garden warblers Sylvia borin during long-distance migration. L Avian Biol 29: 529-535.

Bordel R. and E. Haase. 2000. Influence of flight on protein catabolism, especially myofilament breakdown, in homing pigeons. L Comp Physiol B 170:51-58.

Burger M.F. 1997. Estimating lipid and lean masses in a wintering passerine: an evaluation of TOBEC. Auk 114:762-769.

Connell C.E., E.P. Odum, and H. Kale. 1960. Fat-free weights of birds. Auk 77:1-9.

Daan S., D. Masman, and A. Groenewold. 1990. Avian basal metabolic rates: their association with body composition and energy expenditure in nature. Am I Physiol 259:R333-R340.

Dobush G.R., C.D. Ankney, and D.G. Krementz. 1985. The effect of apparatus, extraction time, and solvent on lipid extractions of snow geese. Can I Zool 63:1917-1920.

Faenestil D.D. 1977. Hyposmolar syndromes. Pp. 267-284 in T.E. Andreoli, J.J. Grantham, and F.C. Rector, eds. Disturbances of Body Fluid Osmolality. American Physiological Society, Bethesda, Md.

Gannes L.Z. 2002. Mass change pattern of blackcaps refueling during spring migration: evidence for physiological limitations to food assimilation. Condor 104:231-239.

Gaunt A.S. and L.W. Oring, eds. 1997. Guidelines to the Use of Wild Birds in Research. 2d ed. North American Ornithological Council, Washington, D.C.

Gevaert D., J. Nelis, and B. Veraenghe. 1991. Plasma chemistry and urine analysis in induced polyuria in racing pigeons Columba livia. Avian Pathol 20:379-386.

Goldstein D.L. and E. Skadhauge. 2000. Renal and extrarenal regulation of body fluid composition. Pp. 265-298 in G.C. Whittow, ed. Sturkie's Avian Physiology. Academic Press, New York.

Herrera C.M. 1982. Seasonal variation in the quality of fruits and diffuse coevolution between plants and avian dispersers. Ecology 63:773-785.

Hicks D.L. 1967. Adipose tissue composition and cell size in fall migratory thrushes (Turdidae). Condor 69:387-399.

Hume I.D. and H. Biebach. 1996. Digestive tract function in the long-distance migratory garden warbler, Sylvia borin. I Comp Physiol B 166:388-395.

Johnson R.A., M.F. Willson, J.N. Thompson, and R.I. Bertin. 1985. Nutritional values of wild fruits and consumption by migrant frugivorous birds. Ecology 66:819-827.

Jordano P. 1988. Diet, fruit-choice, and variation in body con- 
dition of fruigivorous warblers in Mediterranean scrubland. Ardea 76:193-209.

Karasov W.H. and B. Pinshow. 1998. Changes in lean mass and in organs of nutrient assimilation in a long-distance migrant at a springtime stopover site. Physiol Zool 71:435-448.

- 2000. Test for physiological limitation to nutrient assimilation in a long-distance passerine migrant at a springtime stopover site. Physiol Biochem Zool 73:335-343.

Klaassen M. and H. Biebach. 1994. Energetics of fattening and starvation in the long-distance migratory garden warbler, Sylvia borin, during the migratory phase. I Comp Physiol 164:362-371.

Klaassen M., Å. Lindström, and R. Zijlstra. 1997. Composition of fuel stores and digestive limitations to fuel deposition rate in the long-distance migratory thrush nightingale, Luscinia luscinia. Phvsiol Zool 70:125-133.

Lee K.A., W.H. Karasov, and E. Caviedes-Vidal. 2002. Digestive response to restricted feeding in migratory yellow-rumped warblers. Physiol Biochem Zool 75:314-323.

LeMaho Y., J.V.V. Ka, H. Koubi, G. Desasmes, G. Girard, J. Ferre, and M. Cagnard. 1981. Body composition, energy expenditure, and plasma metabolites in long-term fasting geese. Am J Physiol 241E:342-354.

Levey D.J. and A. Grajal. 1991. Evolutionary implications of fruit-processing limitations in cedar waxwings. Am Nat 138: 171-189.

Levey D.J. and W.H. Karasov. 1989. Digestive responses of temperate birds switched to fruit or insect diets. Auk 106:675686.

Levey D.J. and C. Martínez del Rio. 2001. It takes guts (and more) to eat fruit: lessons from avian nutritional ecology. Auk 118:819-831.

Lindström Å. 1995. Stopover ecology of migrating birds: some unsolved questions. Isr J Zool 41:407-416.

Lindström Å., A. Kvist, T. Piersma, A. Dekinga, and M. Dietz. 2000. Avian pectoral muscle size rapidly tracks body mass changes during flight, fasting and fuelling. LExp Biol 203: 913-919.

Lindström Å. and T. Piersma. 1993. Mass changes in migrating birds: the evidence for fat and protein storage re-examined. Ibis 135:70-78.

Marsh R.L. 1984. Adaptations of the gray catbird Dumetella carolinensis to long-distance migration: flight muscle hypertrophy associated with elevated body mass. Physiol Zool 57: 105-117.

Martin A.C., J.S. Zim, and A.L. Nelson. 1951. American wildlife and plants: a guide to wildlife food habits. McGraw-Hill, New York.

Martínez del Rio C., J.E. Schondube, T.J. Mcwhorter, and L.G. Herrera. 2001. Intake responses in nectar feeding birds: digestive and metabolic causes, osmoregulatory consequences, and coevolutionary effects. Am Zool 41:902-915.

McLandress M.R. and D.G. Raveling. 1981. Changes in diet and body composition of Canada geese before spring migration. Auk 98:65-79.

McWhorter T.J. and C. Martínez del Rio. 2000. Does gut function limit hummingbird food intake? Physiol Biochem Zool 73:313-324.

McWilliams S.R. and W.H. Karasov. 2001. Phenotypic flexibility in digestive system structure and function in migratory birds and its ecological significance. Comp Biochem Phvsiol 128: 579-593.

- 2004. Migration takes guts: digestive physiology of migratory birds and its ecological significance. In P. Marra and R. Greenberg, eds. Birds of Two Worlds. Johns Hopkins University Press, Washington, D.C.

Moore F. and P. Kerlinger. 1987. Stopover and fat deposition by North American wood-warblers (Parulinae) following spring migration over the Gulf of Mexico. Oecologia 74:4754.

Murphy M.E. and J.R. King. 1982. Semi-synthetic diets as a tool for nutritional ecology. Auk 99:165-167.

Murphy M.E., J.R. King, and L. Jianjiian. 1989. Malnutrition during the postnuptial molt of white-crowned sparrows: feather growth and quality. Can J Zool 66:1403-1413.

Odum E.P., D.T. Rogers, and D.L. Hicks. 1964. Homeostasis of nonfat components of migrating birds. Science 143:10371039.

Parrish J.D. 1997. Patterns of frugivory and energetic condition in nearctic landbirds during autumn migration. Condor 99: 681-697.

- 2000. Behavioral, energetic, and conservation implications of foraging plasticity during migration. Stud Avian Biol 20:53-70.

Piersma T. 1990. Pre-migratory "fattening" usually involves more than the deposition of fat alone. Ringing Migr 11:113115.

- 1998. Phenotypic flexibility during migration: optimization of organ size contingent on the risks and rewards of fueling and flight. L Avian Biol 29:511-520.

Piersma T. and R.E.J. Gill. 1998. Guts don't fly: small digestive organs in obese bar-tailed godwits. Auk 115:196-203.

Piersma T., G.A. Gudmundsson, and K. Lilliendahl. 1999. Rapid changes in the size of different functional organ and muscle groups during refueling in a long-distance migrating shorebird. Physiol Biochem Zool 72:405-415.

Pyle P. 1997. Identification Guide to North American Birds. I. Slate Creek, Bolinas, Calif.

Rappole J.H. and D.W. Warner. 1976. Relationships between behavior, physiology and weather in avian transients at a migration stopover site. Oecologia 26:193-212.

SPSS. 1999. SPSS 10.0. SPSS, Chicago.

Stark J.M. 1999. Structural flexibility of the gastro-intestinal tract of vertebrates: implications for evolutionary morphology. Zool Anz 238:87-101. 
Terres J.K. 1996. The Audubon Society Encyclopedia of North American Birds. Wings Books, New York.

Thompson J.N. and M.F. Willson. 1979. Evolution of temperate bird/fruit interactions: phenological strategies. Evolution 33: 973-982.

Witmer M.C. 1998. Ecological and evolutionary implications of energy and protein requirements of avian frugivores eating sugary diets. Physiol Biochem Zool 71:599-610.
Witmer M.C. and P.J. Van Soest. 1998. Contrasting digestive strategies of fruit-eating birds. Funct Ecol 12:728-741.

Yong W. and F.R. Moore. 1997. Spring stopover of intercontinental migratory thrushes along the northern coast of the Gulf of Mexico. Auk 114:263-278.

Zwarts L., B.J. Ens, M. Kersten, and T. Piersma. 1990. Moult, mass and flight range of waders ready to take off for longdistance migrations. Ardea 78:339-364. 